\title{
APPEARANCE, DISAPPEARANCE AND REAPPEARANCE OF ACTIVITY BASED COSTING: A CASE STUDY FROM A SRI LANKA MANUFACTURING FIRM
}

\author{
Chamali Wijerathne $^{1}$ and Tharusha Gooneratne ${ }^{2}$ \\ ${ }^{1}$ University of Colombo, Sri Lanka \\ Email: chamaliwijerathne1@gmail.com \\ ${ }^{2}$ University of Colombo, Sri Lanka \\ Email: tharushng@dac.cmb.ac.lk / tharushang@yahoo.com
}

\begin{abstract}
The purpose of this paper was to identify why activity based costing (ABC) implementation in organizations at times do not continue despite their early interest, but later regain importance. Using the qualitative case study approach, the paper explored the reasons for the appearance, disappearance and reappearance of $\mathrm{ABC}$ drawing field data from a Sri Lankan porcelain manufacturing firms, called Gamma. Guided by the theoretical underpinnings of the Actor-Network Theory (ANT), and the translation process therein, we follow organizational managers (human actors) and their interactions with various objects and systems (non-human actors) within the particular context of Gamma, during the different phases of the ABC project. Our findings suggest that the appearance, disappearance and reappearance of $\mathrm{ABC}$ have been shaped by a network of actors comprising both humans and non-humans, and that the implementation and continuation of $\mathrm{ABC}$ is constrained by the interests of these various actors both inside and outside of the firm. While most prior research has focused on a single phase of $\mathrm{ABC}$ implementation, such as the success or the failure, this study brings out its reappearance, following a phase of appearance and disappearance, hence it is a useful addition to prior literature. Furthermore, the findings of this research have important implications for practitioners who are striving to revive projects, such as $\mathrm{ABC}$ in organizations.
\end{abstract}

Keywords: activity based costing, appearance, disappearance, reappearance, actor-network theory, case study

$\underline{\text { ARTICLE INFO }}$

Article History:

Received: 21 May 2019

Accepted: 30 October 2019

Published: 31 December 2019 


\section{INTRODUCTION}

Traditional management accounting systems have been subjected to widespread criticisms in the 1980's by practitioners as well as academics. Questions have thus been raised on their relevance in providing useful information for decision making given the dynamisms of the environment encountered by contemporary business firms (Johnson \& Kaplan, 1987). Within this backdrop, a number of new techniques have been developed to bring back the lost relevance of management accounting. Activity based costing (ABC) introduced by Cooper and Kaplan in 1988 is one such tool. $\mathrm{ABC}$ has gained prominence as a technique that strives to overcome the weaknesses of traditional costing approaches by employing multiple cost drivers to allocate overhead costs (Clarke, Hill, \& Stevens, 1999; Innes \& Mitchell, 1997). ABC, first assigns costs into activities and then costs are allocated based on identified cost drivers for each activity. As its proponents espouse, an ABC system enhances the accuracy of product costing (Innes \& Mitchell, 1997), offers more relevant product cost information for managerial decisions (Major \& Hopper, 2005), helps in identifying non-value adding activities and serves as a better tool for pricing (Lere, 2000). The ABC technique has diffused to various countries in the world (Bjornenak, 1997; Joshi, 2001), and there are numerous ABC success stories in the literature (Kurumeweide, 1998; Shields, 1995). Despite its advantages, the technique has been subjected to criticisms as well. Some claim that ABC merely redefines conventional overhead costing (Armstrong, 2002). Innes, Mitchell, and Sinclair (2000) as well as Major and Hopper (2005) found that managers resist $\mathrm{ABC}$ adoption in their organizations due to high costs and complexities. Amid all this, claims have also been made as to whether ABC is still relevant (Stratton, Desroches, Lawson, \& Hatch, 2009), for not all $\mathrm{ABC}$ implementations sustain, and some firms even move back to traditional costing after unsuccessful $\mathrm{ABC}$ episodes.

Literature highlights behavioral, operational and implementation issues which have led to unsuccessful ABC experiences in organizations (Malmi, 1997; Major \& Hopper, 2005; Bhimani \& Pigott, 1992). Researchers call for more studies claiming that in some organizational settings ABC is unlikely to sustain no matter how skillfully the implementation is managed (Malmi, 1997; Anderson, Hesford, \& Young, 2002), while certain organizations move back to $\mathrm{ABC}$ reviving their earlier unsuccessful projects. Although 
important, currently little is known on the reasons behind such changing fates of $\mathrm{ABC}$, thus the focus of this study. We shed light on the $\mathrm{ABC}$ experience of a porcelain manufacturing firm in Sri Lanka, Gamma, tracing the changing fate of its $\mathrm{ABC}$ project from the successful appearance in 2004 to its discontinuation in 2006 and reappearance in 2016. More particularly, this paper provides evidence on the reappearance of $\mathrm{ABC}$; an area which prior studies have laid limited emphasis, by addressing the following research questions: what motivated $\mathrm{ABC}$ implementation in the case organization?; why did $\mathrm{ABC}$ not continue; and why did it later reappear? Accordingly, we demonstrate that the appearance, disappearance and reappearance of $\mathrm{ABC}$ in Gamma are shaped by a network of human and non-human actors both inside and outside the organization. This study forms a significant addition to the existing body of management accounting literature, and provides valuable insights to practicing managers on reviving, once discontinued management accounting techniques, using $\mathrm{ABC}$ as an example.

The rest of the paper is organized as follows. Section two reviews past literature on $\mathrm{ABC}$, and section three presents the research context, followed by the theoretical lens and methodology of the study in sections on four and five, respectively. The findings of the research are offered in section six, while section seven presents a discussion of findings and conclusions.

\section{LITERATURE REVIEW}

There is an extensive body of literature surrounding various facets of $\mathrm{ABC}$ ranging from its theoretical merits, conceptual weaknesses and behavioral issues in practice (Askarany, Yazdifar, \& Askary, 2010; Banker, Bardhan, \& Chen, 2008; Bjornenak,1997; Cardes \& Gooneratne, 2016; Demeere, Stouthuysen, \& Roodhooft, 2009; Innes \& Mitchell, 1997; Jones \& Dugdale, 2002; Kaplan et al., 2014; Malmi, 1997; Major \& Hopper, 2005; Öker \& Özyapici, 2013; Shield, 1995; Schulze, Seuring, \& Ewering, 2012; Stratton et al., 2009). The literature claims that the key feature of ABC is that it employs multiple cost drivers to allocate overhead costs (Innes \& Mitchell, 1997), being an information system that assists in decision making (Swenson, 1995), and a map of the company's costs and profitability based on business operations (Cooper \& Kaplan, 1988). Studies by Major and Hopper (2005) as well as Innes et al. (2000) have concluded that following 
the adoption of $\mathrm{ABC}$, the costs of organizations become more accurate and controlled. Assigning overhead costs of activities for orders, customers and products based on actual resource consumption as done through ABC provide organizations with novel insights on products, customers and competitors (Innes et al., 2000), and can be used to enhance product pricing (Lere, 2000). Accordingly, the role of manufacturing practices in mediating the impact of activity-based costing on plant performance (Banker et al., 2008), applying ABC in a supply chain environment (Schulze et al., 2012; Askarany et al., 2010). Complementarily effects of the balanced scorecard (BSC) and ABC on organizational performance (Maiga \& Jacob, 2003) as well as time-driven activity-based costing have been the focus of past researchers (Demeere et al., 2009; Kaplan et al., 2014; Öker \& Özyapici, 2013).

Despite its theoretical merits, authors have raised concerns regarding the technical efficiency of ABC, as an overhead allocation system. Friedman and Lyne (1995) as cited in Gossellin (2007) argue that given the nature of allocations being arbitrary, decisions based on allocated costs will also be doubtful, as possibilities exist for more than one way of allocation, with equally valid rationales. Prior literature also points out that $\mathrm{ABC}$ implementations give rise to conflicts among professional groups due to shift in the authority and alterations in the power base of managers (Bhimani \& Pigott, 1992; Major \& Hopper, 2005). Furthermore, problems in identifying cost drivers and direct allocation methods make it difficult for organizations to adopt and maintain ABC (Major \& Hopper, 2005; Malmi, 1997; Innes et al., 2000).

Regardless of these alleged weaknesses, many organizations which have implemented $\mathrm{ABC}$ have often gained productive results by successfully managing technical, organizational and behavioral factors (Innes et al., 2000; Shield, 1995). Shields (1995) found that ABC success is more linked to behavioral and organizational factors, such as top management support, integration with competitive strategy initiatives, such as total quality management (TQM) and just-in-time (JIT), performance evaluation and compensation, non-accounting ownership of the project, training provided in design, implementation and use of $\mathrm{ABC}$ and the provision of adequate resources. Shedding light on this further, Krumwiede (1998) suggested that the critical success factors change at different stages of ABC 
implementation. While weaknesses of traditional costing systems, large size of the organization and IT infrastructure facilities were important at the early stage of adoption of $\mathrm{ABC}$, top management support, non-accounting ownership and training were critical for the success during the later stages. In addition, the need for strategic planning, continuous improvement, high competition and sophisticated technology add to the success of ABC (Baird, Harrison, \& Reeve, 2004; Drury, 2000).

Notwithstanding the above, although management accounting practices, such as $\mathrm{ABC}$ are more transferable across national boundaries, both supply and demand barriers exist. In their study based in Ireland, Clarke et al. (1999) note that lack a supply of innovative managerial accountants stemming from the absence of compulsory continuing professional education, practitioner journals and executive MBA programmes devoted specifically to management accounting as barriers. Gosselin (2007) also states that many organizations have still not considered the adoption of $\mathrm{ABC}$, and that some firms which have implemented have also abandoned the technique. This is further confirmed through the survey study done by Innes et al. (2000), on the adoption of ABC among UK's largest companies in 1994, and a follow up study in 1999 to identify the levels of ABC success. They concluded that some companies which have implemented $\mathrm{ABC}$ subsequently abandoned it; some investigated and rejected it; while certain others discarded the idea and never explored its possible use.

Given its claimed theoretical merits and such differing levels of successes, failures and revivals in practice, $\mathrm{ABC}$ is a topic worthy of inquiry. However, most research to date has been in the form of factor studies, which identify critical factors that lead to its failure. Accordingly, resistance of managers due to high cost and complexity, lack of top management support, problems related to efficacy of $\mathrm{ABC}$, difficulties in selecting cost drivers and identifying cost activities and resistance of employees are found to be the major factors that leads to its failure (Innes \& Mitchell, 1997; Innes et al., 2000; Malmi, 1997; Jones \& Dugdale, 2002; Major \& Hopper, 2005: Bhimani \& Pigott, 1992). Malmi (1997) claims that although factor studies of $\mathrm{ABC}$ failures are invaluable during the early stages of its adoption, more empirical studies seeking alternative and complementary explanations relating to successes and failures in practice are required across time. Focusing on this point, and extending prior literature, this study addresses 
the research issue of why $\mathrm{ABC}$ implementation in organizations at times do not continue despite their early interest, however later gets re-introduced. Although important, this to date has received limited research attention. Moreover, through the review of prior literature, it was evident that past $\mathrm{ABC}$ studies has often focused on a single stage of implementation, such as the design, implementation, sustainability or discontinuation, and that the revival of the technique following its discontinuation in an organizational setting has been scantly explored. The current study fills this apparent gap in prior literature by providing empirical evidence on the changing fates of an $\mathrm{ABC}$ project in terms of its appearance, disappearance and reappearance in the context of a manufacturing firm in Sri Lanka over a period of time (2004-2016).

\section{RESEARCH CONTEXT}

The empirical setting of this research, which is refered to as Gamma, due to confidentiality reasons was established over thirty years ago as a fully owned subsidiary of a Sri Lankan government entity, and privatized several years after being established. Gamma has a highly skilled and experienced workforce of over 1,000 employees, and a majority of them reside within a radius of about 15 kilo meters to Gamma. The firm depicts a relatively tall organization structure consisting of chairman/board of directors, corporate management team, senior managers, managers, executives, supervisors, and manufacturing floor level workers, spread across various functional departments, such as factory, international marketing, local sales, supplies and logistics, stores, finance, human resources and administration as well as internal audit. The core of the organization is the factory, where the production of exclusive tableware takes place. Gamma caters to a niche export market, and is renowned for the high quality in its designs and decorations, having won numerous awards in the areas of exports, productivity and quality over the years. It has a manufacturing capacity of about 1.6 million pieces per month and over $85 \%$ of its products are exported to Europe, USA as well as various countries in Asia. Local sales are carried out through their own show-rooms and agents.

Gamma has been popularly known for its receptiveness towards contemporary management practices, for it has embraced various 
management tools to enhance its competitiveness and efficiency. Such tools include quality circles, 5S, Kaizen, TQM and in the accounting front, an $\mathrm{ABC}$ system, as became evident through the firm's published records. Gamma was thus selected as the context for this research to obtain an indepth understanding of its ABC system. Initially, contacts were established with a key member of the finance division capitalizing on a personal contact, and permission was thereafter obtained from the top management to explore the $\mathrm{ABC}$ system in-depth. Based on a preliminary discussion with a key manager of the firm it was apparent that until 2004 Gamma operated with a traditional costing system. In 2004, ABC was introduced to the firm, and it was successfully implemented until 2005. In 2006, the firm had discontinued $\mathrm{ABC}$ and moved back to traditional costing, while in $2016 \mathrm{ABC}$ was re-introduced.

\section{THEORETICAL LENS}

To illuminate the actor-network relationships behind the changing fate of $\mathrm{ABC}$ in the particular organizational context of Gamma, this paper uses actor-network theory (ANT) as the theoretical lens (see Callon, 1986a, 1986b; Latour, 1987, 1999, 2005). ANT can be used to explore how an innovation (such as $\mathrm{ABC}$ ) is diffused and becomes rooted in a setting. While the pioneers of an innovation employ allies to promote and develop it, various other actors make alliances with them to achieve their own interests (Lowe, 2001a). Connections are thus made with different actors, and these connections form "actor networks" comprising of both human and non-human actors. The notion of a network is central to ANT, as rather than identifying isolated actors, ANT is concerned with interactions among actors, and how networks are constructed through mobilizing actor interests (Latour, 1987, 2005). ANT thus explains how actor-networks are formed and how they can fall apart (Callon, 1986a, 1986b). A key characteristic of ANT is the symmetrical treatment of human and non-human actors (Lowe, 2001a). As Latour (2005) describes while both people and objects exist in society, the interactions between people (human), objects and technology (non-humans) creates society. In the management accounting arena, systems, procedures, documents and physical devices (Lowe, 2001b; Jones \& Dugdale, 2002; Sandhu, Baxter, \& Emsley, 2008) are seen to participate in such interactions, and are example of non-human actors. Networks become 
stronger as they attract more and more human and non-human allies, and an innovation becomes successful when it acquires a solid appearance or becomes a 'black box' (Latour \& Woolgar, 1979 as cited in Alcouffe, Berland, \& Levant, 2008). Seeing in this manner, ANT espouses that the success of an innovation depends on many actors, other than its pioneers, such as the users of the innovation and their expectations, interests as well as problems faced (Lowe, 2001b).

ANT has been widely used as a theoretical lens by management accounting researchers. This ranges from studies on inter-organizational relationships (Chua \& Mahama, 2007) and intra-organizational relationships (Sandhu et al., 2008; Ushio \& Kazusa, 2013; Endenich, Trapp \& Brandau, 2017). More particularly, it has provided theoretical support in understanding the implementation and localization of new tools such as ABC (Briers \& Chua, 2001; Alcouffe et al., 2008), BSC (Sandhu et al., 2008), management control and integration (Dechow \& Mouritsen, 2005), as well as accounting change (Justesen \& Mouritsen, 2011). Seen through the lens of ANT, formulation of intellectual capital statements (Mouritsen \& Larsen, 2005), construction of benchmarks (Llewellynn \& Northcott, 2005), development of audit expertise (Gendron, Cooper \& Townlay, 2007), role of accounting in the creation of new markets (MacKenzie, 2009), as well as ERP system implementation (Quattrone \& Hopper, 2005) has also been subjected to scholarly inquiry.

Notwithstanding these research endeavors, in the current body of literature there is limited understanding on the changing fates of management accounting techniques within a particular organizational setting overtime seen through the lens of ANT. Using an ABC example and drawing upon the theoretical ideas of ANT, this research addresses this void by illuminating how the different phases of $\mathrm{ABC}$ in Gamma have been shaped through interactions among human and non-human actors and the networks formed. In doing so, we also draw on the concept of translation under ANT. Translation implies the means by which an actor enrolls others in the creation of an actor-network, entailing attempts by innovators to form a central forum (network), in which all actors agree that the network is worth building and defending. Problematization, interessement enrolment and mobilization are the four moments of the translation process (Callon, 1986a, 1986b). Problematization is actors' efforts to show the merits of 
the systems/processes espoused by them, and interessement refers to the actions of getting other actors interested and convinced towards the system. Enrolment is creating alliance with other actors, while mobilization is where the actors in the network accept (become aligned to) and act collectively. The translation process has been subjected to scholarly inquiry by prior researchers, such as in the areas of successes and failures of the diffusion processes (Alcouffe et al., 2008) and business process change failure (Sarker, Sarker, \& Sidorova, 2006). Through this paper we extend the use of ANT (and the translation process) in management accounting research by illuminating the changing fate of $\mathrm{ABC}$ in our case study firm, Gamma.

\section{METHODOLOGY}

Keeping with similar research leaning on ANT (Alcouffe et al., 2008; Briers \& Chua, 2001; Justesen \& Mouritsen, 2011; Lowe, 2001a) to capture the actor-network relationships amid the changing fate of $\mathrm{ABC}$ in the particular organizational context of Gamma, this paper adopts the qualitative methodology (Silverman, 2000, 2006) and single-site case study approach (Yin, 2009). Such a methodological orientation appeared apt in addressing the research questions of this study, such as, what motivated $\mathrm{ABC}$ implementation in the case organization; why did $\mathrm{ABC}$ not continue; and why did it later reappear?

\section{Data Collection}

Prior to entering the field to collect data, desk research was carried out by referring to the company website, annual reports, newspaper articles as well as industry capability reports of ceramic industry of Sri Lanka to gain a general understanding of the research context. During this period a number of telephone conversations that span around 15 minutes were also held with AGM-Finance to get an overview about the ABC project in the firm. Following this, a number of in-depth interviews were conducted in March to April 2017 in the factory location of Gamma. Initially, a 40 minutes interview was conducted with AGM-Finance, who was the head of the steering committee that led the ABC implementation in the organization. Thereafter, key actors involved in the implementation were identified for further investigation. Accordingly, in-depth interviews were conducted 
with seven members in different hierarchical levels in Gamma and with one consultant to the $\mathrm{ABC}$ project. Interviews spanned between 15 minutes to two hours. Table 1 presents the designations of the interviewees along with the duration of the interviews.

Table 1: Interview Details

\begin{tabular}{ll}
\hline \multicolumn{1}{c}{ Designation of the Interviewee } & \multicolumn{1}{c}{ Duration of the Interviews } \\
\hline AGM- Finance & Three hours (3 interviews) \\
Previous Cost Accountant & Thirty Minutes - telephone interview \\
Assistant Cost Accountant & Thirty Minutes \\
Whiteware Supervisor & Twenty Minutes \\
Production Manager & Twenty Minutes \\
Marketing Manager & Fifteen Minutes \\
Corporate Sales Manager & Thirty Minutes \\
Local Consultant to the project & Two Hours \\
\hline
\end{tabular}

All interviews were conducted in the native language (Sinhala) for the ease of communication as the interviewees appeared more comfortable in doing so. Thereafter the interviews were translated to English. Five of the interviews were tape recorded and transcribed verbatim, while detailed hand written notes were taken during the other three interviews. Further, interview data was triangulated with data obtained through documentary review. ABC related documents reviewed in the firm, included cost calculation sheets and $\mathrm{ABC}$ reports as well as documents of the local consultant to the $\mathrm{ABC}$ implementation project.

\section{Data Analysis}

Transcripts of interviews, detailed notes taken and documents collected from Gamma were analyzed in isolation as well as taken together as a whole. Then, main themes were identified, and these themes were further analyzed in-depth in relation to the theoretical lens, ANT. Thereafter coding was carried out. The initial codes were rather broad categories, 'a 
provisional start list' (as Miles \& Huberman described it). Analysis of the initial interviews guided the subsequent data collection in order to 'follow up on surprises' and in deciding on aspects worthy of further investigation. As the fieldwork advanced based on emerging themes additional codes were identified, and actors' interpretations were reproduced using direct quotes within a particular theme. In this manner an in-depth understanding of the data was developed. It was decided to carry out the process of coding and categorizing of data manually, with the aid of Microsoft Word and Excel. In doing so, proper records were maintained. Data were organized and displayed in summary tables (listing the main codes and interviewees' comments), which facilitated in the analysis of diverse views of interviewees.

\section{Maintaining Credibility}

Regardless of the methodological roots, scholars need to address credibility issues in their research, which is commonly judged by validity and reliability. However, in qualitative field studies, validity and reliability cannot be easily distinguished (Ahrens \& Chapman, 2006), and the means to achieving them is not standardized or routine, but situation - and timespecific, as by nature these studies are more varied and contextually dependent (McKinnon, 1988).

In terms of qualitative field work, McKinnon (1988) proposed three strategies which could be followed during data collection to minimize threats to validity and reliability. This includes increasing the time spent in the research setting; using multiple methods of data collection; and maintaining good rapport with participants. Accordingly in this research, firstly, more than 12 hours were spent conducting interviews and reviewing documents. Secondly, triangulation of data gathered through multiple methods (in-depth interviews and documentary review) was utilized to ascertain whether the data corroborated each other. Thirdly, cordial relations were maintained with interviewees, assuring confidentiality of data. Furthermore, the data collection process was done systematically, whenever permitted interviews were voice recorded and carefully transcribed and detailed hand written notes were maintained for other interviews. 


\section{EVIDENCE FROM THE FIELD}

Interview evidence gathered and the review of $\mathrm{ABC}$ related documents revealed that since its inception, for over two decades until 2003 the case study firm, Gamma used traditional costing techniques for computation of product cost, preparation of financial reports, taxation purposes and for provision of information for internal management purposes. In 2004, ABC was introduced to the firm under the guidance of two consultants; although discontinued in year 2006. ABC nevertheless reappeared in the management accounting landscape of the firm in year 2016. See Table 2.

Table 2: Changing fate of $A B C$ in Gamma

\begin{tabular}{|c|c|c|c|}
\hline Phase & Period & $\begin{array}{l}\text { Costing } \\
\text { system }\end{array}$ & $\begin{array}{l}\text { Human / non-human } \\
\text { actors }\end{array}$ \\
\hline $\begin{array}{l}\text { Phase one: } \\
\text { Appearance of } A B C\end{array}$ & $2004-2005$ & $A B C$ system & $\begin{array}{l}\text { - CEO } \\
\text { - AGM-Finance } \\
\text { - Middle managers } \\
\text { - Limitations of traditional } \\
\text { costing system }\end{array}$ \\
\hline $\begin{array}{l}\text { Phase two: } \\
\text { Disappearance of } \\
\text { ABC }\end{array}$ & 2006-2015 & $\begin{array}{l}\text { Traditional } \\
\text { costing }\end{array}$ & $\begin{array}{l}\text { - Retirement of the } \\
\text { earlier CEO } \\
\text { - Statutory constraint }\end{array}$ \\
\hline $\begin{array}{l}\text { Phase three: } \\
\text { Reappearance of } \\
\text { ABC }\end{array}$ & $\begin{array}{l}2016 \\
\text { onwards }\end{array}$ & $\begin{array}{l}\text { ABC system } \\
\text { and traditional } \\
\text { costing }\end{array}$ & - ERP system \\
\hline
\end{tabular}

The sub-sections to follow present the findings of this research in terms of the various phases of the ABC project of Gamma along with the key human and non-human actors during each phase.

\section{Phase One: Appearance of $A B C$}

\section{Forming an $A B C$ network}

The appearance of ABC in Gamma in 2004 was led by a network consisting of human and non-human actors. The CEO at that time, AGMFinance and other middle level managers played a significant role in this regard. For instance, the $\mathrm{CEO}$ at that time brought in the idea of $\mathrm{ABC}$ to Gamma and enrolled allies to support it. As AGM- Finance commented: 
Our CEO took the initiative, actually it was his idea. We implemented it because it was the need of the time as we had identified some weaknesses in our traditional costing system. We also had the need for cost management and to know accurate costs of the products.

The Cost Accountant at that time held the same view as he said, "it was the CEO's idea, Mr.... (name). After that we (finance department) introduced it to the organization, a cross functional team was also appointed". Assistant Cost Accountant who was a trainee in the Finance department at the time of introducing $\mathrm{ABC}$ reinforced the above adding:

We needed to know the exact costs of the products and wanted to implement a proper cost management system. One of the main reasons for the implementation of $A B C$ was that our $C E O$ also had the same idea. There's no use if a lower level person wanted to implement this, and then the CEO has different goals. This was easy because it came from CEO.

The CEO's keenness in the project became a significant consideration behind the implementation of $\mathrm{ABC}$ in the firm, and following from the CEO's interest other employees became enthusiastic about it. Then CEO of Gamma had been appointed to the position in year 2003. He was a mechanical engineering graduate from a leading local university, and an expert in the field of strategic management and marketing, also holding a master's degree in Marketing. Prior to assuming duties as CEO, he had five years' experience as an executive director and five years' experience as a General Manager of Gamma. He had also guided several major projects in the firm, during the period 2001-2003, such as factory capacity expansion and implementation of a new production strategy. Being receptive towards new techniques he pioneered the introduction of various Japanese manufacturing techniques in the firm, such as quality circles, kaizen, TQM and 5S. His wealth of experience supplemented his academic and professional qualifications in leading Gamma as the CEO.

According to interviewees, the CEO first took measures to convince the senior management on the need to implement $\mathrm{ABC}$ in the organization. AGM-Finance added: 
Until year 2000, our production strategy was to get the design specifications from our international clients, and to produce accordingly, and we marketed them under their labels. But, in 2003 we started to market under our own brand name. So, we came out with a number of new items. Coming to the market under our brand name is very different from producing to the requirements of reputed clients; we need a lot of information to survive in the market. This can be taken as one reason for the introduction of $A B C$.

After, several rounds of discussions with managers, a cross-functional steering committee headed by the AGM-Finance was appointed to facilitate the ABC implementation. AGM-Finance who had joined Gamma in 1991 and serves the firm to date, has witnessed all three phases of $A B C$ in the firm. Being the project leader, he was a key actor behind the $\mathrm{ABC}$ implementation, who attracted more allies towards the $\mathrm{ABC}$ network. Under his guidance managers were sent for $\mathrm{ABC}$ workshops and introductory presentations were also conducted with the help of an Indian Chartered Accountant, who was later recruited as a consultant to the project.

Subsequently, $\mathrm{ABC}$ was initiated in 2004 under the guidance of two consultants, an Indian Chartered Accountant and a local consultant. According to AGM - Finance and the then Cost Accountant, no resistance was shown for the implementation of $\mathrm{ABC}$ by any division of the organization. For, they were also expecting benefits by implementing it in their divisions. According to the Cost Accountant of Gamma, "we introduced $\mathrm{ABC}$ because we wanted to know the actual costs of the products, and in our departments we felt the problems of the traditional systems." He further elaborated the weaknesses that lead to inaccurate cost information in the organization. As he pointed out:

For example, those days we used to allocate machine maintenance cost, based on the book value of the machines, which is so incorrect. So, the new machines which had a higher book value were allocated with lot of maintenance cost, whereas those new machines don't incur such a cost compared to old ones. 
According to the Corporate Sales Manager, $\mathrm{ABC}$ was implemented to facilitate accurate product pricing. He added, "we implemented ABC because, we needed to go for accurate product pricing, and also to identify segment-wise and customer-wise profitability." Those in the production area were interested in $\mathrm{ABC}$ as it facilitated implementation of Kaizen in Gamma. A Production Manager espoused that being an export oriented manufacturing entity, continuous improvement was paramount to maintain the firm's competitiveness and that they've been inspired by Kaizen. He further commented:

After we identified activities throughout the organization, in the base level of this $(A B C)$ we actually implemented Kaizen parallel to this. We didn't stop identifying activities only at the ABC level; we further divided one activity into a series of activities, to micro activities to manage costs as a Kaizen exercise.

AGM - Finance further added how along with the ABC system, Kaizen was also implemented. He went on to say, "we listed every activity for cost controlling purposes in departments. That means not only the activities that we chose for product costing, but we identified every activity in every movement in each department, because of that, we could easily implement Kaizen as well."

As the forgoing interview data suggests the interests and expectations of an array of key managers (human actors from the perspective of ANT) paved the way for the appearance of $\mathrm{ABC}$ in Gamma. For instance, then CEO introduced $\mathrm{ABC}$ to the organization; gave his blessings and formed allies to support the technique. Thus eventually a network was formed through the interactions of these allies. The other actors who served as allies for the new technique also supported $\mathrm{ABC}$ with the expectation of using it for their own interest. For instance, AGM-Finance, previous Cost Accountant and other members in the finance department expressed words of praise about the technique for it helped in increasing the accuracy of product costing and cost control in the organization. Marketing managers lend support to $\mathrm{ABC}$, for in their mind it helped in obtaining accurate information for product pricing and customer profitability analysis. In similar vein, from the worldview of production managers $\mathrm{ABC}$ facilitated process improvements. Seeing in this manner, appearance of $\mathrm{ABC}$ in Gamma was pioneered by the then $\mathrm{CEO}$, 
who also succeeded in enrolling an array of human actors (managers) who supported the project backed by their own interests.

\section{An Overview of the ABC System}

As became apparent through the words of various interviewees and a review of documents, the direct costs in Gamma included direct materials, direct labor, fuel and power costs, as well as packing materials costs. Our interviewees further explained that all other costs were considered as overheads, and were allocated to the 12 broad processes (See Table 3 ) in the firm, based on the actual resource consumption of the particular process.

\section{Table 3: Broad Processes in Gamma}

1. Market development- local

2. Market development- foreign

3. Product development

4. Procurement and storage

5. Selling

6. Production- whiteware

7. Decoration

8. Decal printing

9. Maintenance

10. Quality assurance

11. Production planning

12. Corporate level activities

It was further revealed that out of these 12 processes, procurement and storage, maintenance, quality assurance and production planning were considered as service centers, and that the costs of these service centers were reallocated to production centers. Thereafter other production centers' costs were allocated to the identified cost pools or centers within the broad process. During interview encounters, the AGM - Finance elaborated how the allocation of overhead costs of these production processes was done, using one production process, Production-whiteware as an example. As he 
noted, Production-whiteware is a production center and the total overhead costs of this process is divided into four identified cost pools as Forming, Biscuit firing, Glazing and Whiteware firing. Thereafter, the costs in each of these pools are allocated to activities within each cost pool. For example, overhead costs allocated for Forming cost pool, is then allocated to the four activities identified within the cost pool, such as Slice Cutting and Batting, Forming, Finishing and Inspection, based on the actual resource consumption by each of these activities. See Figure 1.

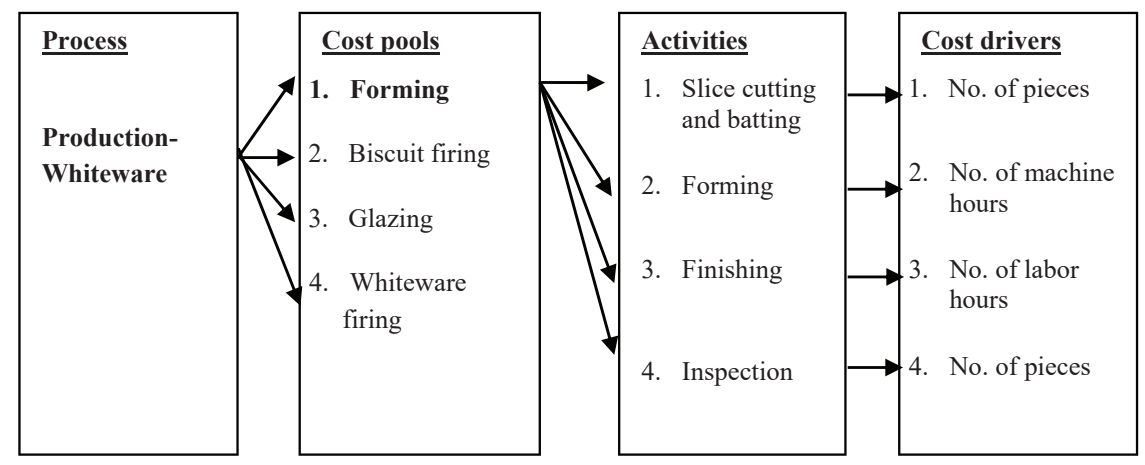

Figure 1: Allocation of Activities to Cost Pools Based on Cost Drivers

Finally, costs of these activities were allocated to products based on the identified cost drivers. According to above example and as depicted in Figure 1, Slice cutting and batting cost are allocated to products based on the number of pieces; forming costs based on machine hours, finishing costs based on labor hours and inspection costs based on the number of pieces. The total cost of a product was calculated in this manner, by allocating all the overhead costs in production centers. Thereafter adjustments were made for damages.

\section{Merits of the ABC System}

Interviewees of Gamma expressed positive sentiments about the new $\mathrm{ABC}$ system, for it provided better information for managerial decision making. As the then Cost Accountant espoused it helped managers to allocate overheads to products in a more accurate manner. He said: 
Now, say there is a certain amount of cost incurred for "Forming". If we look how this Forming cost is consumed by each product, it is basically through machine hours. But the time (machine hours) consumed by a dinner plate is different from a salad plate. In the traditional method we charged a flat rate of $26 \%$ as overhead costs for all the products. This is a weakness in that system. But in ABC method we charge a different rate for each product based on the resource consumption. So, the real profit and loss came out.

Reinforcing the above, the local consultant to the project explained, "now what we do is if one consumes only $18 \%$ then we charge only $18 \%$. If another consumes $10 \%$ then we charge only $10 \%$, so, cost is allocated according to the consumption by each of these segments. So, we can find what the profitable segments are really, and what the loss making ones are." In similar vein, AGM-Finance further explained how ABC helped cost management. He said:

\begin{abstract}
With $A B C$ we get a thorough understanding of cost elements and behavior. Why? Because we do a detailed analysis, we analyze to minor details. You might have seen we analyze this into 2 layers and to 12 processes. So, we can find how much we spent for selling process, how much for product development etc.
\end{abstract}

These interview quotes suggest that $\mathrm{ABC}$ has facilitated in computing accurate product costs and in providing useful information for cost management. As the Assistant Cost Accountant commented, Gamma had identified significant differences between the cost information provided by the traditional costing system and the $\mathrm{ABC}$ system. He said, "we saw a difference in the information in the new system, because our gold and platinum products became costly and B2B became profitable than before".

During interview encounters, the Marketing Manager and the Corporate Sales Manager shared similar views regarding better accuracy of product costing under ABC. Furthermore, the Corporate Sales Manager noted that the $\mathrm{ABC}$ system has provided new insights regarding segmental profitability, as he stated, "Corporate sales became very profitable. So, we focused on expanding that area". He further stated that some marketing 
segments of the organization became loss making and the top management decided to discontinue such segments.

The Marketing Manager went on to explain how ABC facilitated in identifying profitability of various market segments. He added:

With $A B C$, we could identify segment-wise profitability. In our profit \& loss account, marketing overheads come in various ways, like market development, foreign trips, product development etc. but, earlier, nobody was concerned as to which segment used up these costs. With $A B C$, it is possible to see if costs were incurred by the local market, then which segment in the local market?; whether it is dealers?; showrooms or B2B?', actually after we calculated our costs using this technique, B2B became profitable than earlier.

The forgoing comments of the members of the marketing department show how $\mathrm{ABC}$ has helped in directing marketing efforts in a way beneficial to the long term wellbeing of the firm. In a comparable tone, the Production Manager explained how $\mathrm{ABC}$ was useful in the firm's attempts on cost reduction. He went on:

Platinum pieces are one of our profitable products, but our margins reduced as the product became very costly after we did calculations according to ABC. Also, we could identify some lossmaking products as well. We couldn't discontinue loss making products. But, however after identifying those areas we could cut-down some costs. We asked our people to make the gold line thin, to reduce the high cost of gold decorated items.

Apart from that, the Production Manager also pointed out that $\mathrm{ABC}$ led to increase efficiency in the production process, for it analyzes the activities in-detail, and helped in identifying non-value adding activities. As he elaborated:

In this $A B C$ method we use two concepts called value adding activities and non-value adding activities. So, after we find and analyze every activity of the organization we can identify 
non-value adding activities and eliminate them. Now, let's take something like transport, it never adds any value to the product. So, we can eliminate this by, may be putting a conveyer belt, or maybe we can take steps to reduce distance between departments, so likewise we could use some of these concepts to increase efficiency in the department.

Several other interviewees reinforced the above. The Inspection Supervisors in the factory were given the responsibility of collecting cost data for the implementation of $\mathrm{ABC}$, and they noted that when collecting such data, they also get a better understanding about the cost behavior in their departments. This understanding in turn helps them to suggest cost reduction methods. As the Whiteware Inspection Supervisor commented:

We also get an idea about costing when we do such a thing like collecting information needed for $A B C$, so then we also can tell the employees the proper procedures in doing things. Everybody understands it better when we show something from numbers.

Seeing in this manner, the ABC system of Gamma has facilitated accurate product costing and cost control in the organization as expected by the senior management. Despite such advantages, the system was short lived, and was discontinued after a year from its introduction, as elaborated next.

\section{Phase Two: Disappearance of ABC}

Although $\mathrm{ABC}$ was introduced to Gamma with much interest and enthusiasm in 2004, interview evidence revealed that its presence in the firm was short-lived, for $\mathrm{ABC}$ was subsequently discontinued and the firm moved back to the traditional costing system from year 2006. A key constraint for the continuation of $\mathrm{ABC}$ was the regulatory restrictions placed upon Gamma, by the Inland Revenue Department, which can be considered as a non-human actor in ANT terms. The AGM- Finance espoused:

When we traditionally present stock valuation to the Inland Revenue Department, we take direct costs. So, the stock valuation is done based on the direct costs and other production costs of the organization. But when we divided this into processes, it 
includes some of the administration and selling costs also. When this happens, auditors cannot accept our stock valuation. That is the main reason for discontinuation of $A B C$.

This was also pointed out by the then Cost Accountant, stating, "ABC reclassifies our traditional profit and loss account, so the auditors had a problem in accepting it". As he explained:

There are direct costs: direct materials, direct labor, direct energy and then factory overheads. In the traditional system we base our stock valuation only on these factory costs. But in $A B C$, when we take processes, the administration cost, selling and distribution and finance cost, all that comes. In the profit and loss also all those come for the processes. So then when we allocate costs of those processes to products, some part of this administration and finance costs also come to the stock valuation. So we had to change back to traditional system.

On a comparable tone, the Assistant Cost Accountant commented, "ABC is good. But it didn't comply with IFRS and tax regulations. So, because of that we couldn't continue it though we started to implement." Other interviewees expressed similar sentiments regarding the discontinuation of ABC. For instance, the Corporate Sales Manager pointed out:

The auditors told us to run two systems. There's this requirement from Inland Revenue Department that we need to follow a certain procedure for costing. In the production floor, we take line items and do the costing, based on processes. ABC goes based on processes. But we had a resource limitation to do both these at the same time. So we had to stop $A B C$.

As the above interview evidence suggests, while Gamma was not in a position to maintain two systems due to resource constraints, the firm moved back to the traditional system, which was in line with fulfillment of statutory requirements. Our field data also revealed that by this time the CEO, who was much passionate about $\mathrm{ABC}$ had also retired from the organization. This too became a significant reason behind the discontinuation of $\mathrm{ABC}$. As the AGM-Finance explained: 
When we implement a system like $A B C$, we need the commitment of every employee from the CEO. It should become a part of the organizational culture. It should be used and managed by the system. Without that, if we only use this to calculate costs, the interest of employees will be lost. When we only introduce this as a costing system it becomes useless for the person who gives the information, because they can't use it for the management of their own departments. This could have continued if we used $A B C$ for management and budgeting as well. Like if CEO asks for monthly $A B C$ cost reports from each department. Actually, $C E O$ left and the top management didn't ask for any department wise report. If we did that, this could have become a part of the organizational culture.

The Cost Accountant and the Assistant Cost Accountant at that time also shared similar views. All in all, across time, $\mathrm{ABC}$ lost its way in the costing and control arena of Gamma. For instance, amid the departure of the $\mathrm{CEO}, \mathrm{ABC}$ was merely a costing system, and was not developed to a level of being a useful management system in the way of activity based management $(\mathrm{ABM})$ and activity based budgeting (ABB). More importantly, given the need for compliance to statutory requirements taking precedence, and amid the inability of the firm to maintain two systems, discontinuing $\mathrm{ABC}$ was the most tenable option.

\section{Phase Three: Reappearance of ABC}

In year 2014, a new CEO was appointed to the firm, and he took the initiative to implement an enterprise resource planning (ERP) system, which was considered to be a long felt need according to interviewees. The AGM- Finance noted:

Three years back we acquired a subsidiary. With that, our operations further increased. Since then for several years the top management was having the idea of implementing an ERP system. However, it requires a lot of resources. In 2013 and 2014 we didn't have enough resources because we had already done a huge investment in this new subsidiary. So in 2015 we decided to implement this. 
Accordingly, ERP applications were implemented covering the main operations of the firm, such as manufacturing, supply chain, finance, human resources and business intelligence, while also connecting the four main stores in the island. It was installed as a pilot run in 2015, and was used for operations of the firm from mid 2016 (Annual Report Gamma, 2016, 2017). In this manner, with the introduction of the ERP system, ABC reappeared in the firm in 2016. As AGM- Finance commented, "when we installed the new system (ERP), we had to put the activities and the cost drivers at the beginning. It was not our priority to implement $\mathrm{ABC}$ this time, but we were given the facility to use $\mathrm{ABC}$ for our calculations, so we used it". He further explained:

This new ABC is bit different from what we used to have in 2005. The problem we had last time was that we had to implement two systems; $A B C$ and the traditional method because of the Inland Revenue requirements for external reporting, so our managers didn't have enough time to maintain two systems because we did it manually. Although we used the 'excel' package we had to collect information and insert the information manually, analysis and everything was done manually with the experience. So it was difficult. But now we have the cost activities and drivers already inserted when we installed the system itself, so all what we have to do is to extract the report. Of course, there is some work to do, but what I mean is, it is not that difficult to analyze because of the system and also we can do various types of analysis with the system. So we are using ABC again now.

As the forgoing suggests $\mathrm{ABC}$ has now made its presence felt in Gamma powered by the newly implemented ERP system. The ERP system has thus been an important non-human actor which has reinstated the once discontinued $\mathrm{ABC}$ in the firm.

\section{DISCUSSION AND CONCLUSION}

Drawing upon the theoretical ideas of ANT (and the translation process therein), in this paper we highlighted how the changing fate of the $\mathrm{ABC}$ project in Gamma has being shaped by the interactions between an array 
of human and non-human actors. It explored what motivated the firm to implement $\mathrm{ABC}$, why $\mathrm{ABC}$ did not continue, although later re-appeared and how an $\mathrm{ABC}$ network was finally formed.

The field study data shows that the appearance of $\mathrm{ABC}$ in Gamma in 2004 was primarily driven by the keen interest of an influential human actor, the $\mathrm{CEO}$ during that time. Following this interest he problematized the need for $\mathrm{ABC}$, and got other actors in accounting and finance, such as AGM - Finance, then Cost Accountant as well as other functional managers in areas such as marketing and production, who were already aware of the limitations of the traditional costing system interested and convinced towards the $\mathrm{ABC}$ system (interessement). Despite creating an alliance and enrolling key actors towards $\mathrm{ABC}$ in this manner, mobilization, where all organizational members act collectively towards $\mathrm{ABC}$ did not happen as expected. The translation process was not complete; thus $\mathrm{ABC}$ disappeared from Gamma in 2006, and the firm moved back to the traditional costing system.

This shift was particularly due to the inability of the firm to maintain two accounting systems, i.e. to satisfy statutory reporting to Inland Revenue Department of Sri Lanka (via the traditional costing system) and to provide costing information for internal decision making (via the $\mathrm{ABC}$ system). During this time, the firm had a simple accounting and information system, where much of the data had to be manually entered and analyzed. Amid difficulties of maintaining two systems, understandably, external reporting, being a compulsory requirement took precedence over the provision of more accurate cost information to internal management. Seen in this manner, the regulatory barrier placed upon Gamma by the Inland Revenue Department (a non-human actor in ANT terms), prevented materializing an ABC network. Furthermore, the retirement of the key (human) actor, the CEO too led to this end.

Following the arrival of a new CEO in 2014, an ERP system was implemented in $\mathrm{r}$ 2016, which enabled Gamma to extract and analyze information to satisfy both these concerns through a system powered by ERP. The key reason for the disappearance of $\mathrm{ABC}$, which was the system limitation to accommodate two systems, was now addressed, and this led to the reconstruction of the previously faded $\mathrm{ABC}$ network. The translation 
process was thus completed with the introduction of the ERP system, which not only featured $\mathrm{ABC}$, but was able to take $\mathrm{ABC}$ to the next level, in the name of $\mathrm{ABB}$ and $\mathrm{ABM}$. This became appealing to managers across the firm, for they were already convinced about the concept of $\mathrm{ABC}$, and the earlier disappearance of $\mathrm{ABC}$ was due to the inability of the firm's information system to cater to two costing systems simultaneously, rather than due to conceptual lapses of the technique of $\mathrm{ABC}$. Of particular significance, the role of non-human actors was crucial behind the disappearance as well as reappearance of $\mathrm{ABC}$; for while a regulatory barrier marked the disappearance of $\mathrm{ABC}$, implementation of ERP system was instrumental bringing back the once discarded $\mathrm{ABC}$ to the corporate landscape and mobilizing it in the firm.

The fate of a new technique, such as $\mathrm{ABC}$ is fragile, and depends on the strength of the network constructed and the actors attached to it (Alucoffe et al., 2008). Therefore accepting, accommodating and managing diverse human and non-human elements are vital in introducing innovative management techniques (Sandhu et al., 2008). We concur this through our case study findings, where although $\mathrm{ABC}$ was introduced with much enthusiasm in Gamma it did not sustain beyond one year, (although later reintroduced). Furthermore, this paper endorses the findings of Sandhu et al. (2008) which note that a network is also shaped by long ties outside the organization, such as government policies and market forces. In the context of Gamma, government policies in the form of regulations of Inland Revenue Department turned out to be a barrier for the continuation of ABC. Furthermore, reasons linked to market forces, such as the need to keep up with latest trends and maintain competitiveness through the introduction of systems (such as ERP) facilitated its subsequent implementation. Hence the ERP system became significant behind the changing fate and the shaping of $\mathrm{ABC}$ network, in terms of its discontinuation at one point and reintroduction at another point. Putting it succinctly, our findings suggest that appearance, disappearance and reappearance of $\mathrm{ABC}$ have been shaped by a network of actors comprising of both humans and non-humans, and that the implementation and continuation of $\mathrm{ABC}$ is facilitated and constrained by the interests of these human and non-human actors inside and outside the firm. 
The initial adoption of $A B C$ in Gamma is linked to the claimed merits of the technique, in terms of increased accuracy of product costs, which is in par with prior ABC studies (Bhimani \& Pigott, 1992; Innes et al., 2000; Major \& Hopper, 2005). The study by Innes et al. (2000) based on UK firms found that many organizations which have adopted $\mathrm{ABC}$ have done so to increase the accuracy of costing, while Major and Hopper (2005) has revealed that after the adoption of $\mathrm{ABC}$, accuracy of costing has been increased in a Portuguese telecommunication company. Furthermore, Bhimani and Pigott (1992) note that in the pharmaceuticals company under their inquiry, $\mathrm{ABC}$ was implemented pioneered by the Finance Director who acted upon the dissatisfaction voiced by accountants and factory managers about the standard costing system operating at the plant, which allocated costs purely on the basis of production scale with no consideration for non-volume factors. More recently, Cardes and Gooneratne (2016) note how the implementation of ABC in a Sri Lankan conglomerate was linked to the parent company's decision to implement an ERP system. However, focus of Cardes and Gooneratne has been on the institutionalization of $\mathrm{ABC}$, whereas this paper is centered on the changing fates of $A B C$ in a single firm through appearance, disappearance and reappearance, including how the ERP system became a key reason for the reappearance.

Methodologically and in terms of research focus, our paper is also different from that of Banker et al. (2008) which focused on the impact of $\mathrm{ABC}$ on adoption of world-class manufacturing (WCM) practices and plant performance with the aid of a large cross-sectional sample from US, as well as from the survey study based on 83 US manufacturing business units by Maiga and Jacob (2003) which was premised upon the complementarily effects of balanced scorecard (BSC) and ABC on organizational performance. Nevertheless, in par with such prior research Gamma too embraced multiple contemporary tools such as quality circles, 5S, Kaizen, TQM (in addition to $\mathrm{ABC}$ ) to enhance its competitiveness. Furthermore, while ABC in a supply chain environment (Askarany et al., 2010; Schulze et al., 2012) as well as time-driven activity-based costing in the Health care context (Demeere et al., 2009; Kaplan et al., 2014; Öker \& Özyapici, 2013) has been subjected to inquiry by past researchers, in this paper we probe into an $\mathrm{ABC}$ system in the context of a manufacturing firm. 
This paper makes an important contribution to literature as well as to practice. As for the literature, it forms a useful addition to the existing body of management accounting knowledge, particularly relating to $\mathrm{ABC}$. While most prior $\mathrm{ABC}$ studies have focused on either its success or failure, the changing fates of $\mathrm{ABC}$ and its reappearance after an episode of discontinuation (which is the focus of this paper), although important has been scantly explored by past researchers. It also extends ANT inspired management accounting research by presenting an in-depth analysis of actor-network relationships influencing the appearance, disappearance and reappearance of $\mathrm{ABC}$ in a firm. Furthermore, while the translation process (under ANT) has been subject to inquiry by past researchers, in terms of successes and failures of the diffusion processes, business process change failure etc, although apt, it has not been explored in relation to changing fate of management / accounting tools, as done in this paper. From a practical stance, this paper provides important insights to managers in business firms regarding successfully shaping actor networks and reviving discontinued innovative techniques like $\mathrm{ABC}$, following an episode of discontinuation. This is particularly vital for practicing managers, for the theoretical wisdom of $\mathrm{ABC}$ has been put forward decades ago, in practice techniques of this nature ends up in different fates across time in various organizational contexts. Raising the question, "Activity-Based Costing: Is it still Relevant? Stratton et al. (2009) drawing from survey data from 348 manufacturing and service companies worldwide note that $\mathrm{ABC}$ indeed provide significant value to managers, and that it is time for more organizations to take another look at adopting ABC. A decade later (i.e. in 2019), our case study evidence lend support in subscribing to this view.

Moving beyond, this paper also opens up a number of avenues for future research. Since this study is based on a manufacturing firm's experiences with an $\mathrm{ABC}$ project, considering the differing nature of operations and accounting practices, future studies can be conducted focusing on service sector organizations. In addition, further research on the reappearance of $\mathrm{ABC}$ as well as other management accounting techniques, following an era of discontinuation in organizations can be a topic of interest for future inquiry. 


\section{REFERENCES}

Alcouffe, S., Berland, N., \& Levant, Y. (2008). Actor-network and the diffusion of management accounting innovations: A comparative study. Management Accounting Research, 19, 1-17.

Anderson, S. W., Hesford, J. W., \& Young, S. M. (2002). Factors influencing the performance of activity-based costing teams: a field study of $\mathrm{ABC}$ model development time in the automobile industry. Accounting, Organizations and Society, 27, 195-211.

Annual Report Gamma (2016, 2017). Sri Lanka: Gamma.

Ahrens, T., \& Chapman, C. S. (2006). Doing qualitative field research in management accounting: Positioning data to contribute to theory. Accounting, Organizations and Society, 31(8), 819-841.

Armstrong, P. (2002). The costs of activity-based management. Accounting, Organizations and Society, 27, 99-120.

Askarany, D., H Yazdifar, H., \& Askary, S. (2010). Supply chain management, activity-based costing and organisational factors. International Journal of Production, 127(2), 238 - 248.

Baird, K., Harrison, G., \& Reeve, R. (2004). Adoption of activity management practices: A note on the extent of adoption and the influence of organizational and cultural factors. Management Accounting Research, 15, 383-389.

Banker, R. D., Bardhan, I. R., \& Chen, T. Y. (2008). The role of manufacturing practices in mediating the impact of activity-based costing on plant performance. Accounting, Organizations and Society, 33, 1-19.

Bhimani, A., \& Pigott, D. (1992). Implementing ABC: A case study of organizational and behavioural consequences. Management Accounting Research, 3, 119-132.

Bjornenak, T. (1997). Diffusion and accounting: The case of ABC in Norway. Management Accounting Research, 8, 3-17. 
Briers, M., \& Chua, W. F. (2001). The role of actor-networks and boundary objects in management accounting change: A field study of implementation of activity-based costing. Accounting, Organizations and Society, 26(3), 237-269.

Callon, M. (1986a). Some elements of a sociology of translation: Domestication of the scallops and the fishermen of St Brieuc Bay. In Law, J. (Ed.), Power, action and belief. (pp. 196-233). London: Routledge.

Callon, M. (1986b). The Sociology of an Actor-Network: The Case of the Electric Vehicle. In M. Callon, J. Law, and A. Rip. (Eds.), Mapping the dynamics of science and technology: Sociology of science in the real world. (pp. 19-34). London: Macmillan Press.

Cardes, S., \& Gooneratne, T. N. (2016). Institutionalization of activity based costing in a Sri Lankan manufacturing firm: A case study. Colombo Business Journal, 7, 37-51.

Clarke, P., Hill, N., \& Stevens, K. (1999). Activity based costing in Ireland: Barriers to, and opportunities for change. Critical Perspectives on Accounting, 10, 443-468.

Cooper, R., \& Kaplan, R. S. (1988). Measure costs right: Make the right decisions. Harvard Business Review, 96-103.

Chua, W. F., \& Mahama, H. (2007). The effect of network ties on accounting controls in a supply alliance: Field study evidence. Contemporary Accounting Research, 24(1), 47-86.

Dechow, N., \& Mouritsen, J. (2005). Enterprise resource planning systems, management control and the quest for integration. Accounting, Organizations and Society, 30(7/8), 691-733.

Demeere, N., Stouthuysen, K., \& Roodhooft, F. (2009). Time-driven activitybased costing in an outpatient clinic environment: Development, relevance and managerial impact. Health Policy, 92(2-3), 296-304. 
Drury C. (2000). Management and cost accounting. London: Thomson Learning.

Endenich, C., Trapp, R., \& Brandau, M. (2017). Management accounting networks in corporate processes - A cross national study. Journal of Accounting and Organizational change, 13, 25-43.

Gendron, Y., Cooper, D. J., \& Townley, B. (2007). The construction of Auditing expertise in measuring government performance. Accounting, Organisations and Society, 32, 101-129.

Gosselin, M. (2007). A review of activity based costing: Technique, implementation and consequences. Handbook of Management Accounting Research, 2, 641-672.

Innes, J., \& Mitchell, F. (1997). The adoption of activity-based costing in the United Kingdom's largest financial institutions. The Service Industries Journal, 17(1), 190-203.

Innes, J., Mitchell, F., \& Sinclair, D (2000). Activity-based costing in the U.K.'s largest companies: A Comparison of 1994 and 1999 survey results. Management Accounting Research, 11, 349-362.

Johnson, H. T., \& Kaplan R. S. (1987). Relevance lost: Rise and fall of management accounting. Boston: Harvard Business School Press.

Jones, T.C., \& Dugdale, D. (2002). The ABC bandwagon and the juggernaut of modernity. Accounting Organisations and Society, 27, 121-163.

Joshi, P. (2001). The international diffusion of new management accounting practices: The case of India. Journal of International Accounting, Auditing \& Taxation, 10, 85-109.

Justesen, L. \& Mouritsen, J. (2011). Effects of actor-network theory in accounting research. Accounting, Auditing \& Accountability Journal, 24(2), 161-193. 
Kaplan, R. S., Witkowski, M., Abbott, M., Guzman, A. B., Higgins, L.D., Meara, J. G., Padden, E., Shah, A.S., Waters, P., John E. H., Weidemeier, M., Wertheimer, S., Feeley, T.W. (2014). Using time-driven activitybased costing to identify value improvement opportunities in healthcare. Journal of Healthcare Management, 59(6), 399-412.

Krumwiede, K. (1998). The implementation stages of activity-based costing and the impact of contextual and organizational factors. Journal of Management Accounting Research, 10, 239-277.

Latour, B. (1987). Science in action: How to follow scientists and engineers through society. London: Harvard University Press.

Latour, B. (1999). Pandora's hope: Essay on the reality of science studies, London: Harvard University Press.

Latour, B. (2005). Reassembling the Social. An introduction to ActorNetwork-Theory. New York: Oxford University Press.

Lere, J. (2000). Activity-based costing: A powerful tool for pricing. Journal of Business \& Industrial Marketing, 15, 22-33.

Llewellyn, S., \& Northcott, D. (2005). Average hospital. Accounting Organisations and Society, 30, 555-583.

Lowe, A. (2001a). After ANT-An illustrative discussion of the implications for qualitative accounting case research. Accounting, Auditing \& Accountability Journal, 14, 327-351.

Lowe, A. (2001b). Accounting Information systems as knowledge objects: Some effects of objectualization. Management Accounting Research, $12,75-100$.

MacKenzie, D. (2009). Making things the same: Gases, emission rights and the politics of carbon markets. Accounting, Organizations and Society, 34(3-4), 440-455. 
Maiga, A. S., \& Jacob, F. A. (2003). Balanced scorecard, activity-based costing and company performance: an empirical analysis. Journal of Managerial Issues, 15(3), 283-231.

Major, M., \& Hopper, T. (2005). Managers divided: Implementing ABC in a Portuguese telecommunications company. Management Accounting Research, 16, 205-229.

Malmi, T. (1997). Towards explaining activity-based costing failure: Accounting and control in a decentralized organization. Management Accounting Research, 8, 459-480.

McKinnon, J. (1988). Reliability and validity in field research: Some strategies and tactics. Accounting, Auditing \& Accountability Journal, l(1), 34-54.

Mouritsen, J., \& Larsen, H.T. (2005). The second wave of knowledge management: The management control of knowledge resources through intellectual capital information. Management Accounting Research, 16, 371-394.

Öker, F., \& Özyapici, H. (2013). A new costing model in hospital management: Time-driven activity-based costing system. The Health Care Manager, 32(1), 23-36.

Quattrone, P., \& Hopper, T. (2005). A Time-space odyssey: Management control systems in two multi-national organisations. Accounting, Organisations and Society, 30, 735-764.

Sandhu, R., Baxter, J., \& Emsley, D. (2008) Initiating the localisation of a balanced scorecard in a Singaporean Firm. Singapore Management Review, 25-41.

Sarker, S., Sarker, S., \& Sidorova, A. (2006). Understanding business process change failure: An actor network perspective. Journal of Management Information Systems, 23(1), 51-86. 
Schulze, M., Seuring, S., \& Ewering, C. (2012). Applying activity-based costing in a supply chain environment. International Journal of Production Economics, 135, 716-725.

Stratton, W. O., Desroches, D., Lawson, R. A., \& Hatch, T. (2009). Activitybased costing: Is It still relevant? Management Accounting Quarterly, 10(3), 31-40.

Shields, M. (1995). An empirical analysis of firm's implementation experiences with activity-based costing. Journal of Management Accounting Research, 7, 148-166.

Silverman, D. (2000). Doing qualitative research. London: Sage Publications.

Silverman, D. (2006). Interpreting qualitative data: Methods for analyzing talk, text and interaction ( $3^{\text {rd }}$ ed.). London: Sage.

Swenson, D. (1995). The benefits of activity-based cost management to the manufacturing industry. Journal of Management Accounting Research, 7(4), 167-180.

Ushio, S., \& Kazusa, Y. (2013). The development of accounting calculations as chronological network effects: Growth rings of accounting calculations. Journal of Accounting and Organizational Change, 9, 380-407.

Yin, R. (2009). Case study research design and methods (4th ed.). USA: Sage Publications. 